\title{
A CONCEPTUAL FRAMEWORK OF ENTREPRENEURIAL ORIENTATION, FINANCIAL LITERACY, AND MSMES PERFORMANCE: THE ROLE OF ACCESS TO FINANCE
}

\author{
Hamdana', Heri Pratikto², Sopiah ${ }^{3}$ \\ Malang State University ${ }^{1,2,3}$, Mulia University ${ }^{1}$ \\ E-mail : hamdana@students.um.ac.id', \\ heri.pratikto.fe@um.ac.id², sopiah.fe@um.ac.id ${ }^{3}$
}

\begin{tabular}{|c|c|}
\hline $\begin{array}{l}\text { Keyword: } \\
\text { Entrepreneurial } \\
\text { Orientation, } \\
\text { Financial Literacy, } \\
\text { Access to Finance, } \\
\text { MSMEs } \\
\text { Performance }\end{array}$ & $\begin{array}{l}\text { Abstract This article intended to address a research } \\
\text { vacuum by identifying the elements that impact MSMEs' } \\
\text { financial performance, including the importance of access } \\
\text { to finance, and establishing a conceptual framework that } \\
\text { explains the link between these factors. The author } \\
\text { proposed a building conceptual framework of MSMEs } \\
\text { finance classic phenomena. A qualitative analysis } \\
\text { approach may be used to establish and construct } \\
\text { conceptual frameworks. This paper has combined } \\
\text { knowledge from various relevant and reputable literature } \\
\text { sources to build a conceptual model. If empirically } \\
\text { verified, the suggested framework might be a viable } \\
\text { option for supporting MSME owners in more successfully } \\
\text { growing their businesses. }\end{array}$ \\
\hline & \\
\hline
\end{tabular}

\section{Introduction}

MSMEs (Micro, Small, and Medium Enterprises) account for the majority of enterprises in Indonesia. According to the Ministry of Cooperatives and Small and Medium Enterprises' (Kementrian KUKM, 2021) report data on the development of Micro, Small and Medium Enterprises (MSME) and Large Enterprises in 2019, there are 65,465,497 MSME units out of a total of 65,471,134 MSME units and only 5,550 large enterprises. MSMEs control 


\section{Hamdana, Heri Pratikto, Sopiah}

around 98.67 percent of the market. Many MSMEs, with a rate of 96.92 percent, engage in labor absorption.

In comparison to major corporations, SMEs contribute the most to GDP. MSMEs provide a major contribution to the Indonesian economy, according to these figures. According to studies undertaken by (Mostapha, 2016), (Agyei, 2018), and others, micro, small, and medium firms play a significant role in Indonesia and other nations (Mor, Madan, Archer, \& Ashta, 2020). According to (Tambunan, 2019) MSMEs play an important role for a variety of reasons. MSMEs, for example, thrive in rural regions and may boost the rural economy, create jobs, and foster entrepreneurship, as well as provide women with business prospects.

This does not mean that MSMEs have convenience in developing their business. MSMEs still often experience delays in running their business. Many basic issues, such as finance and other issues linked to company management, have yet to be fully handled, making it difficult for MSMEs to compete with major corporations. The existence of such intense competitive pressure has a direct or indirect impact on the performance of MSMEs. Entrepreneurial orientation and financial literacy are required in running a firm since these two factors are thought to aid MSMEs in obtaining financing and increasing their performance. Low financial literacy may be a factor in MSMEs' difficulties in acquiring financing (Susan, 2020). This financial literacy is connected to MSME owners' understanding of banking, such that MSME owners are unaware of the procedures and methods for obtaining financing. In addition, the MSME financial administration and management system has not been successfully implemented. As a result, banks and other financial institutions are unable to assess the financial health of SMEs.

Entrepreneurship is a creative and imaginative aptitude that is utilized as a foundation and resource for pursuing business prospects. The ability to innovate, the ability to take risks, and the proactive character are three essential elements of organizational inclinations for entrepreneurial management processes, according to some management literature. Entrepreneurial orientation, in theory, refers to the policies and practices that serve as the foundation for entrepreneurial decisions and activities. Entrepreneurship orientation is defined as the process of developing 
entrepreneurial strategies that entrepreneurs employ to achieve their objectives, preserve their vision, and gain a competitive edge. (Mason, Floreani, Miani, Beltrame, \& Cappelletto, 2015). The techniques for developing company strategies that provide a framework for entrepreneurial choices and actions are referred to as EO (Lumpkin \& Dess, 1996). Entrepreneurial Orientation has five aspects, according to (Lumpkin \& Dess, 1996): Competitive Aggressiveness or competitive aggressiveness, Autonomy or autonomy, Risk-taking or risk-taking, Proactivity or proactiveness, and Competitive Aggressiveness of competitive aggressiveness.

Entrepreneurship orientation is seen as the process of creating entrepreneurial strategies used by entrepreneurs to set goals, maintain their vision, and create a competitive advantage. So, talking about strategy, access to finance is an effort to achieve a competitive advantage. Due to the scale of MSMEs, access to financial capital is the thing that differentiates them from their competitors at the same level. The nature of entrepreneurial orientation is strongly emphasized on the willingness of MSMEs to innovate in it.

Most MSMEs rely on internal financing or the services of specialized financial institutions. Internal borrowing sometimes involves the injection of new capital from the owner's savings and retained or undistributed profits from the business earned in previous years. Access to credit remains an obstacle for MSMEs in terms of working capital. In RBV theory, financial resources complement strategic management by concentrating the firm's efforts on asset accumulation. Sufficient financial variables have a hugely beneficial impact on a small firm's survival and growth, and without them, a small business would struggle to survive. Financial resources were discovered to be critical for MSMEs' survival. However, the lack of financial resources by entrepreneurs is the most significant obstacle to business expansion and growth. MSMEs have difficulty in acquiring financial resources to pursue growth prospects. These various things have caused MSMEs in Indonesia to experience difficulties in expanding to a global level. So that business performance both financially and non-financially becomes a problem faced by MSMEs.

One of the most important aspects of financial inclusion is financial literacy (Hasan, Le, \& Hoque, 2021). Financial literacy is defined by the Organization for Economic Co-operation and Development (OECD) as "a mix of awareness, knowledge, skill, attitude, and behavior required to make smart financial decisions and attain individual financial wellness" (OECD/INFE, 2018). Financial literacy allows people who were previously illiterate or uneducated to become 


\section{Hamdana, Heri Pratikto, Sopiah}

highly educated, as well as increasing the number of people who utilize financial goods and services. The owner's financial literacy has a significant impact on MSME success (Satiti, 2020). Financial literacy helps business owners prepare the business's financial strategies, improve business performance, and acquire the right financial knowledge and skills to maintain sustainability.

According to (Eton, 2017) lack of assets and weak financial foundations often make it difficult for MSMEs globally to conduct and expand market share, as a result of which inadequate equity capital invested in MSMEs makes these businesses more dependent on other sources such as bank loans and other types of financial credit. Most SMEs depend on internal financing or the services of specialized financial institutions. Internal borrowing sometimes involves the injection of new capital from the owner's savings, and retained or undistributed profits from the business earned in previous years. Access to credit remains an obstacle for MSMEs in terms of working capital.

Credit is one source of funds that can be used by business actors in meeting business operational needs. Some credit objectives are in the microeconomic approach, the purpose of providing credit is to obtain added value for both the customer (the debtor) and the bank as a creditor. For customers as debtors, obtaining credit aims to overcome financing difficulties and increase business and income in the future. For the bank itself, it is also expected that the provision of credit will generate interest income as a substitute for the price of the loan itself. In the macroeconomic approach, lending is one of the instruments to maintain the balance of the money supply in the community.

The firm's aims of remaining standing or existing (Survive), earning a profit (Benefit), and being able to develop (Growth) may all be met if the organization performs well. Sales, profit, return on capital, turnover, and market share earned by the company may all be used to assess its performance. Human resources (owners, managers, and workers), financial elements, manufacturing technical aspects, and marketing aspects all influence MSME success. Management is required to increase returns for MSME owners, while also improving employee welfare. This can only happen if MSMEs make a profit in their business activities. Generally, financial performance is used as a basis for measuring whether a company is healthy or not. The financial performance of a corporation is used as a subjective measuring medium to describe the success of a company's asset management in growing revenue. There is no consensus on how to measure performance in MSMEs, which necessitates the development of a method that can be used at the MSME level. 
The balanced scorecard (BSC) is one of the most commonly utilized strategies. This is a performance measuring approach that takes into account both financial and non-financial factors. It was created in 1996 by (Kaplan \& Norton, 1992). Unfortunately, because MSMEs' circumstances differ greatly from those of large corporations, this strategy is not the ideal match for them (Rita \& Thren, 2019). (Aribawa, 2016) developed a non-cost performance metrics technique to assess the financial and non-financial performance of MSMEs. Because the measurement is easier (based on perception), it is hoped that it will be able to provide an overview of the current state of MSMEs. In the future, education will be required to assess the company's performance using simple indicators such as business growth, total revenue (sales), total orders, and cash position. MSME Performance can also be measured by finance (Hudson, Smart, Bourne, Hudson, \& Bourne, 2001), productivity (De Toni \& Tonchia, 2001), quality (Hudson et al., 2001); (De Toni \& Tonchia, 2001), and customer satisfaction (Hudson et al., 2001).

\section{Research Method}

This paper used a qualitative approach with the data analysis model from Miles and Huberman which divides the data analysis activities from data collection, data reduction, data display, and conclusion drawing or verification (Huberman, 1994). The following are the steps of the Miles and Huberman model data analysis method: The main activity in each research is collecting data. Firstly, the author selects the topic to get the article collected. This paper collects data by searching for reputable international articles from Google Scholar and Library Databases such as Springer, Science Direct, and Emerald using the variable name as predetermined keywords.

Data reduction entails summarizing, selecting the essentials, focusing on the most significant aspects, and searching for themes and patterns (Huberman, 1994). Because the amount of data collected in the field is substantial, it must be meticulously recorded. By picking articles that meet the requirements and are focused on the issue, the data was reduced.

A display is a well-organized, condensed collection of facts that enables conclusions to be drawn and action to be taken (Huberman, 1994). Once data is reduced, the author presents the data in the form of a matrix or article review table. By presenting the data, it will be easier for the author to find research gaps and plan further work. This stage is performed by presenting an organized collection of information with the capacity to make conclusions, because the material gathered during the process of qualitative research is generally in the 


\section{Hamdana, Heri Pratikto, Sopiah}

form of the story, needing simplicity without decreasing its contents. A conclusion is made once the evidence has been presented.

As soon as the data is obtained, the qualitative analysis begins, looking for regularities, patterns, explanations, alternative configurations, causal processes, and assertions (Huberman, 1994). The next step is concluding the research gaps and finding a new conceptual model framework that is expected to be used for further research.

\section{Result and Discussion}

Based on the article search conducted by the author using the specified variable keywords, the number of articles obtained is as follows:

Tabel 1.Data Collection of Articles

\begin{tabular}{|c|c|c|c|c|}
\hline \multirow[b]{2}{*}{ Keyword } & \multicolumn{4}{|c|}{ Number of Research Articles } \\
\hline & $\begin{array}{l}\text { Google } \\
\text { Scholar }\end{array}$ & ScienceDirect & Emerald & Springer \\
\hline $\begin{array}{l}\text { Entrepreneurial } \\
\text { Orientation and } \\
\text { Access to Finance } \\
\text { MSME }\end{array}$ & 12,800 & 368 & 77 & 13 \\
\hline $\begin{array}{l}\text { Finance Literacy } \\
\text { and Access to } \\
\text { Finance MSME }\end{array}$ & 7,270 & 35 & 30 & 27 \\
\hline $\begin{array}{l}\text { Entrepreneurial } \\
\text { Orientation and } \\
\text { MSME } \\
\text { Performance }\end{array}$ & 13,700 & 56 & 102 & 13 \\
\hline $\begin{array}{l}\text { Finance Literacy } \\
\text { and MSME } \\
\text { Performance } \\
\end{array}$ & 6,530 & 27 & 30 & 19 \\
\hline $\begin{array}{l}\text { Access to Finance } \\
\text { and MSME } \\
\text { Performance }\end{array}$ & 14,100 & 160 & 176 & 85 \\
\hline $\begin{array}{l}\text { Entrepreneurial } \\
\text { Orientation, } \\
\text { Access to Finance } \\
\text { and MSME } \\
\text { Performance }\end{array}$ & 13,600 & 34 & 77 & 11 \\
\hline $\begin{array}{l}\text { Finance Literacy, } \\
\text { Access to Finance } \\
\text { and MSME }\end{array}$ & 5,960 & 25 & 30 & 18 \\
\hline
\end{tabular}


Performance

The authors filtered the articles found in the following way:

a. The article has variables related to the relationship variables used by the author

b. The data are review articles and research articles

c. The data consists of articles from 2012-2021

d. International articles found to be reputable and indexed by Copernicus, Sinta, or Scopus

e. Articles that have been found and then the author conducts a review by looking at the influence of the related variables

By filtering the data above, the number of articles obtained are as follows:

Table 2. Data Reduction of Articles

\begin{tabular}{ll}
\hline \multicolumn{1}{c}{ Keyword } & $\begin{array}{c}\text { Number of } \\
\text { Research Articles }\end{array}$ \\
\hline $\begin{array}{l}\text { Entrepreneurial Orientation and Access to Finance } \\
\text { MSME }\end{array}$ & 6 \\
\hline Finance Literacy and Access to Finance MSME & 6 \\
\hline Entrepreneurial Orientation and MSME Performance & 7 \\
\hline Finance Literacy and MSME Performance & 7 \\
\hline Access to Finance and MSME Performance & 5 \\
\hline $\begin{array}{l}\text { Entrepreneurial Orientation, Access to Finance and } \\
\text { MSME Performance }\end{array}$ & 3 \\
\hline $\begin{array}{l}\text { Finance Literacy, Access to Finance and MSME } \\
\text { Performance }\end{array}$ & 2 \\
\hline
\end{tabular}

The following is the gap research table as data collection of article review collected by the author.

Table 3. References of Research Article

\begin{tabular}{ccc}
\hline No & $\begin{array}{c}\text { Relationship Between } \\
\text { Variables }\end{array}$ & References \\
\hline
\end{tabular}




\begin{tabular}{|c|c|c|}
\hline 1 & $\begin{array}{l}\text { Entrepreneurial } \\
\text { Orientation and Access to } \\
\text { Finance }\end{array}$ & $\begin{array}{l}\text { (Fatoki, 2012);(Sidek, Mohamad, \& } \\
\text { Nasir, 2016); (Fatima \& Bilal, 2020); } \\
\text { (Zarrouk, Sherif, Galloway, \& El Ghak, } \\
\text { 2020); (Rizki Agung Putra, Firdausi } \\
\text { Nuzula, \& Khalid Mawardi, 2021); } \\
\text { (Khan, Salamzadeh, Kawamorita, \& } \\
\text { Rethi, 2021) }\end{array}$ \\
\hline 2 & $\begin{array}{l}\text { Finance Literacy and } \\
\text { Access to Finance }\end{array}$ & $\begin{array}{l}\text { (Adomako, Danso, \& Ofori Damoah, } \\
\text { 2016); (Dewi, 2018), (Hussain, Salia, \& } \\
\text { Karim, 2018); (Ye \& Kulathunga, 2019); } \\
\text { (Frempong et al., 2021); (Buchdadi, } \\
\text { Sholeha, Ahmad, \& Mukson, 2020) }\end{array}$ \\
\hline 3 & $\begin{array}{l}\text { Entrepreneurial } \\
\text { Orientation and MSME } \\
\text { Performance }\end{array}$ & $\begin{array}{l}\text { (Rita \& Wahyudi, 2019); (Alvarez- } \\
\text { Torres, Lopez-Torres, \& Schiuma, 2019); } \\
\text { (Isichei, Emmanuel Agbaeze, \& Odiba, } \\
\text { 2020); (Kiyabo \& Isaga, 2020); } \\
\text { (Wijayanto, Wahyullah, \& Aribawa, } \\
\text { 2020); (Ardhi, Mulyo, \& Irham, 2021); } \\
\text { (Ferreira, Fernandes, Kraus, \& } \\
\text { McDowell, 2021) }\end{array}$ \\
\hline 4 & $\begin{array}{l}\text { Finance Literacy and } \\
\text { MSME Performance }\end{array}$ & $\begin{array}{l}\text { (Mabula \& Ping, 2018); (Wijayanto et } \\
\text { al., 2020); (Satiti, 2020); (Kulathunga, } \\
\text { Ye, Sharma, \& Weerathunga, 2020); } \\
\text { (Utami, Aprilia, \& Putra, 2021); (Nakita } \\
\text { Gusman, Subiakto Soekarno, 2021); } \\
\text { (Buchdadi et al., 2020) }\end{array}$ \\
\hline 5 & $\begin{array}{l}\text { Access to Finance and } \\
\text { MSME Performance }\end{array}$ & $\begin{array}{l}\text { (Fatoki, 2012); (Mabula \& Ping, 2018); } \\
\text { (Rajamani \& A, 2019); (Buchdadi et al., } \\
\text { 2020);(Rizki Agung Putra et al., 2021); }\end{array}$ \\
\hline 6 & $\begin{array}{l}\text { Entrepreneurial } \\
\text { Orientation, Access to } \\
\text { Finance and MSME } \\
\text { Performance }\end{array}$ & $\begin{array}{l}\text { (Sidek et al., 2016); (Zarrouk et al., } \\
\text { 2020); (Rizki Agung Putra et al., 2021); }\end{array}$ \\
\hline 7 & $\begin{array}{l}\text { Finance Literacy, Access to } \\
\text { Finance and MSME } \\
\text { Performance }\end{array}$ & (Dewi, 2018); (Buchdadi et al., 2020) \\
\hline
\end{tabular}

The following Figure 1 is the proposed conceptual framework: 


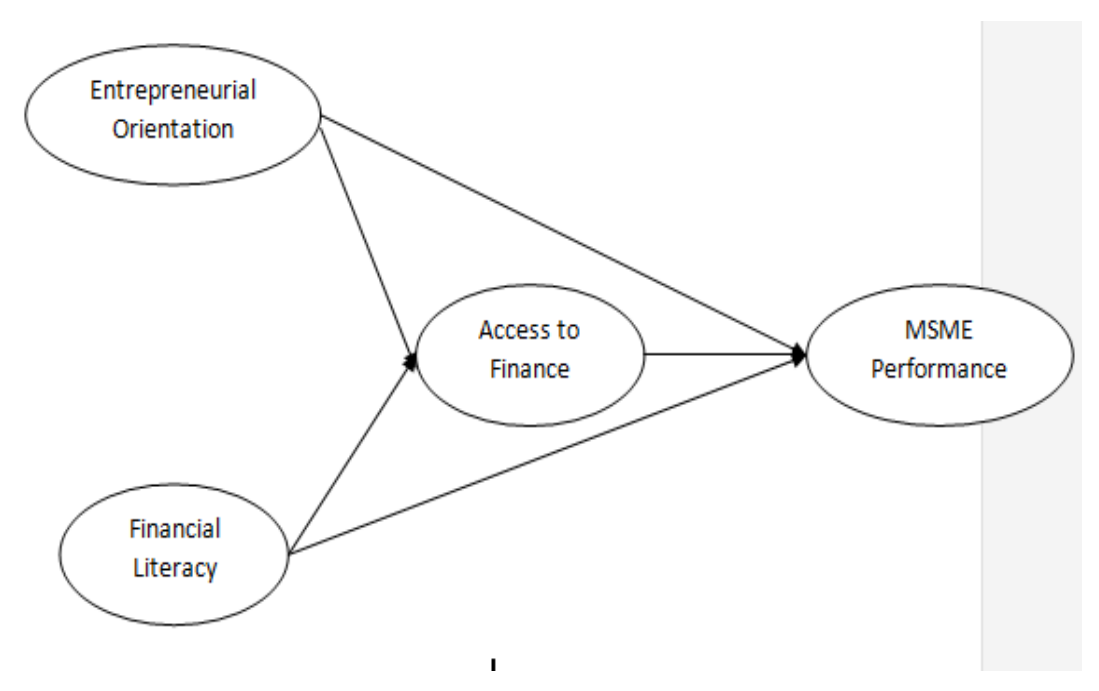

Figure 1. Proposed Conceptual Framework

Based on the conceptual framework, the hypothesis below were proposed:

$\mathrm{H} 1$ : The link between entrepreneurial orientation and access to finance has a beneficial effect

$\mathrm{H} 2$ : The link between Financial Literacy and Access to Finance has a beneficial effect

H3: The association between entrepreneurial orientation and MSME performance has a beneficial effect

H4: The association between financial literacy and MSME performance has a beneficial effect

H5: There is a favorable correlation between MSME performance and access to finance

H6: With Access to Finance as a Mediating Variable, there is a favorable influence in the link between Entrepreneurial Orientation and MSME Performance

H7: With Access to Finance as a Mediating Variable, there is a beneficial influence in the link between Financial Literacy and MSME Performance.

The design suggested by the author is an observational quantitative design with a cross-sectional study approach. The data collection method that can be used is a questionnaire distributed to MSME owners or managers. Future research can use structural equation modeling to test the existing hypothesis. Each dimension or variable indicator that can be used is obtained from the research 
Hamdana $^{1}$, Heri Pratikto ${ }^{2}$, Sopiah ${ }^{3}$ :

article with the table describing the variables below:

Table 4. Dimension or Indicator Based on References

\begin{tabular}{|c|c|c|c|c|}
\hline No & Variable & $\begin{array}{l}\text { Dimension or } \\
\text { Indicator }\end{array}$ & $\begin{array}{l}\text { Measuring } \\
\text { Range }\end{array}$ & References \\
\hline 1 & $\begin{array}{l}\text { Entrepreneurial } \\
\text { Orientation }\end{array}$ & $\begin{array}{l}\text { Pro-activeness } \\
\text { Risk Taking } \\
\text { Competitive } \\
\text { Aggressiveness } \\
\text { Autonomy } \\
\text { Innovativeness }\end{array}$ & $\begin{array}{l}\text { 5-point } \\
\text { Likert scale } \\
\text { (from } \\
\text { "strongly } \\
\text { disagree" = } \\
1 \text { "strongly } \\
\text { agree" = 5) }\end{array}$ & $\begin{array}{l}\text { (Lumpkin \& } \\
\text { Dess, 1996); } \\
\text { (Bolton \& Lane, } \\
\text { 2012); (Kiyabo } \\
\text { \& Isaga, 2020) }\end{array}$ \\
\hline 2 & Financial Literacy & $\begin{array}{l}\text { We can prepare } \\
\text { monthly income } \\
\text { reports. We've gotten } \\
\text { bookkeeping training. } \\
\text { We are aware of the } \\
\text { paperwork necessary } \\
\text { to get a bank loan. We } \\
\text { are well-versed in } \\
\text { accounting and can } \\
\text { produce basic } \\
\text { bookkeeping. We can } \\
\text { figure out how much it } \\
\text { costs to borrow } \\
\text { money. I am aware of } \\
\text { the costs and } \\
\text { advantages of credit. } \\
\text { We have a savings } \\
\text { account for our } \\
\text { company. I can } \\
\text { accurately compute } \\
\text { interest rates and loan } \\
\text { installments. We have } \\
\text { the ability to reduce } \\
\text { losses by reducing } \\
\text { poor credit. We can } \\
\text { examine our accounts } \\
\text { frequently. We have } \\
\text { the expertise to } \\
\text { evaluate a company's } \\
\text { possibilities. }\end{array}$ & $\begin{array}{l}\text { 5-point Likert } \\
\text { scale (from } \\
\text { "strongly } \\
\text { disagree" = } 1 \\
\text { to "strongly } \\
\text { agree" = 5) }\end{array}$ & $\begin{array}{l}\text { (Volpe, 1998); } \\
\text { (Buchdadi et al., } \\
\text { 2020); }\end{array}$ \\
\hline
\end{tabular}




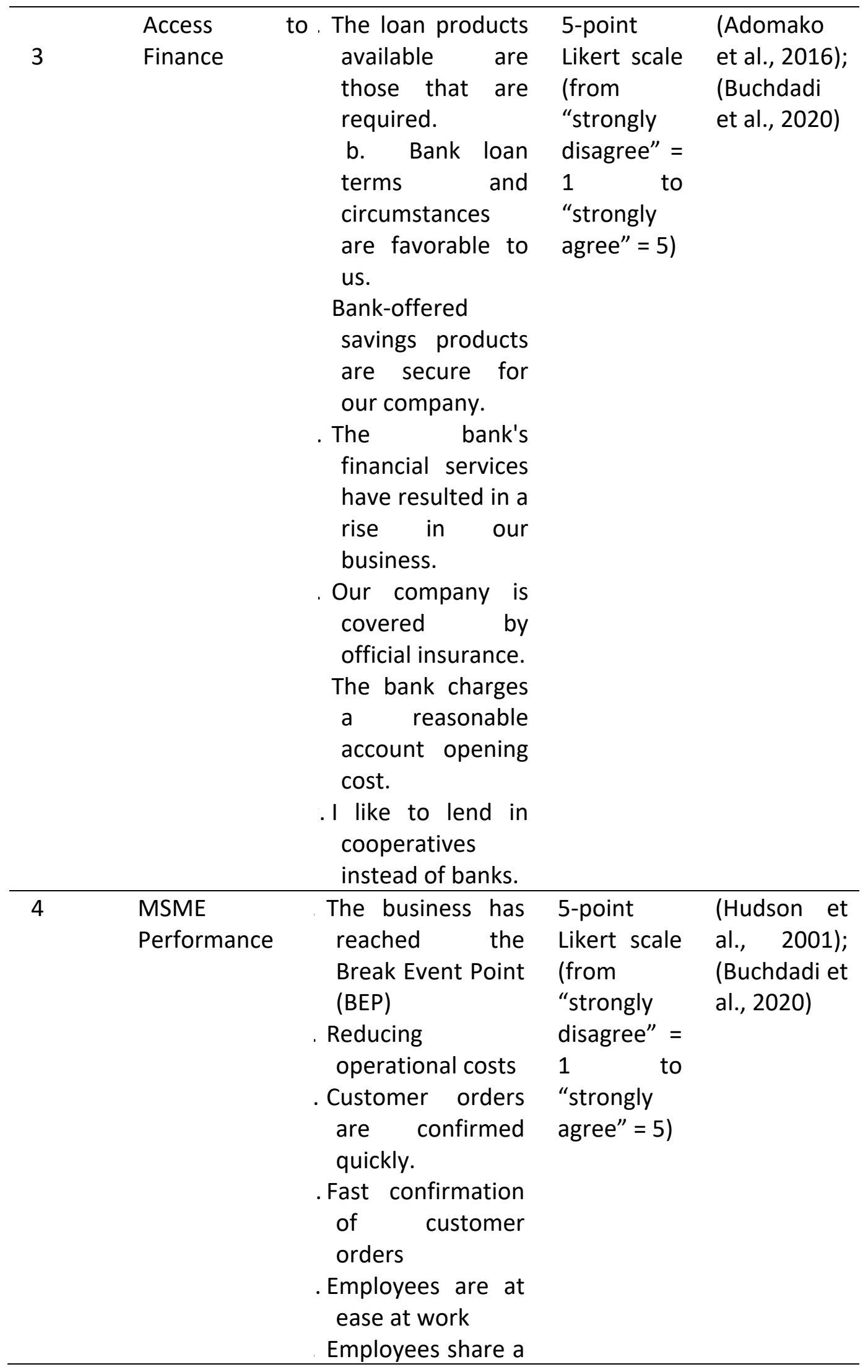




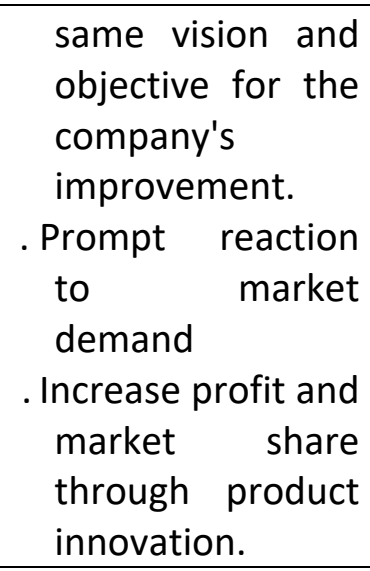

\section{Conelusion}

MSMEs have an important role in the Indonesian economy because they make a significant contribution, especially in the formation of gross domestic product and employment. MSMEs are also seen to have strong economic resilience, allowing them to contribute to the financial system's an economy's stability. MSMEs, on the other hand, continue to encounter many challenges, one of which is financial access. The authors show the importance of access to money in mediating the link between entrepreneurial orientation, financial literacy, and MSME success, based on a survey of related research. The authors conducted a data analysis model from Miles and Huberman by collecting data, reducing data drawing conclusions, and drawing conclusions/verification. After performing the data analysis method, the authors formulated a conceptual framework with seven hypotheses. The authors hope that the conceptual framework of the formulated model can be adopted by further researchers to provide empirical evidence of the model.

\section{References}

Adomako, Samuel, Danso, Albert, \& Ofori Damoah, John. (2016). The moderating influence of financial literacy on the relationship between access to finance and firm growth in Ghana. Venture Capital, 18(1), 43-61. https://doi.org/10.1080/13691066.2015.1079952

Agyei, Samuel Kwaku. (2018). Culture, financial literacy, and SME performance in Ghana. Cogent Economics and Finance, 6(1). https://doi.org/10.1080/23322039.2018.1463813 
Alvarez-Torres, Francisco Javier, Lopez-Torres, Gabriela Citlalli, \& Schiuma, Giovanni. (2019). Linking entrepreneurial orientation to SMEs' performance: Implications for entrepreneurship universities. Management Decision, 57(12), 3364-3386. https://doi.org/10.1108/MD-11-2018-1234

Ardhi, M. Khalifatul, Mulyo, Jangkung Handoyo, \& Irham. (2021). How does entrepreneurial orientation affect the business performance of coffee shop MSMEs in Indonesia? E3S Web of Conferences, 306, 03011. https://doi.org/10.1051/e3sconf/202130603011

Aribawa, Dwitya. (2016). Pengaruh Literasi Keuangan Terhadap Kinerja dan Keberlangsungan UMKM di Jawa Tengah. Siasat Bisnis, 20 NO. 1, 1-13. https://doi.org/https://doi.org/10.20885/jsb.vol20.iss1.art1

Bolton, Dawn Langkamp, \& Lane, Michelle D. (2012). Individual entrepreneurial orientation : development of a measurement instrument. 54(2), 219-233. https://doi.org/10.1108/00400911211210314

Buchdadi, Agung Dharmawan, Sholeha, Amelia, Ahmad, Gatot Nazir, \& Mukson. (2020). the Influence of Financial Literacy on Smes Performance Through Access To Finance and Financial Risk Attitude As Mediation Variables. Academy of Accounting and Financial Studies Journal, 24(5), 1-16.

De Toni, A., \& Tonchia, S. (2001). Performance measurement systems Models, characteristics and measures. International Journal of Operations and Production Management, 21(1-2), 46-70. https://doi.org/10.1108/01443570110358459

Dewi, Winona Kumara. (2018). the Performance of SMEs (Small and Medium Enterprises) in the Trade Sector of Padang City. International Journal of Progressive Sciences and Technologies (IJPSAT), 10(2), 371-381.

Eton, Marus. (2017). Credit Financing and Performance of SMEs in Lira Municipality, Uganda Credit Financing and Performance of SMEs in Lira Municipality , Uganda. Journal of Finance and Accounting, 8(8), 121-127.

Fatima, Tehreem, \& Bilal, Ahmad Raza. (2020). Individual Entrepreneurial Orientation, Access to Finance, and SME Performance: Fortifying Role of Entrepreneurial Alertness. Abasyn University Journal of Social Sciences, 13(1), 233-248. https://doi.org/10.34091/AJSS.13.1.17

Fatoki, Olawale. (2012). The Impact of Entrepreneurial Orientation on Access to Debt Finance and Performance of Small and Medium Enterprises in South Africa. Journal of Social Sciences, 32(2), 121-131. https://doi.org/10.1080/09718923.2012.11893058

Ferreira, João J., Fernandes, Cristina I., Kraus, Sascha, \& McDowell, William C. (2021). Moderating influences on the entrepreneurial orientation-business performance relationship in SMEs. International Journal of Entrepreneurship and Innovation, 22(4), 240-250. https://doi.org/10.1177/14657503211018109

Frempong, Lady Nadia, Acheampong, Monica Owusu, Twumasi, Martinson 


\section{Hamdana, Heri Pratikto, Sopiah}

Ankrah, Jiang, Yuansheng, Wang, Pengcheng, \& Ding, Zhao. (2021). Does financial literacy inevitably lead to access to finance services? Evidence from rural ghana. Ciencia Rural, 52(3). https://doi.org/10.1590/0103$8478 \mathrm{cr} 20210112$

Hasan, Morshadul, Le, Thi, \& Hoque, Ariful. (2021). How does financial literacy impact on inclusive finance? Financial Innovation, 7(1). https://doi.org/10.1186/s40854-021-00259-9

Huberman, Matthew B. Miles \&. A. Michael. (1994). Qualitative Data Analysis: An Expanded Sourcebook. CEUR Workshop Proceedings, Vol. 1304. Sage Publications, Inc.

Hudson, Mel, Smart, Andi, Bourne, Mike, Hudson, Mel, \& Bourne, Mike. (2001). Theory and practice in SME performance measurement systems - 2001 International Journal of Op.pdf. International Journal of Operations \&Production Management, 21(8), 1096-1115.

Hussain, Javed, Salia, Samuel, \& Karim, Amin. (2018). Is knowledge that powerful? Financial literacy and access to finance: An analysis of enterprises in the UK. Journal of Small Business and Enterprise Development, 25(6), 985-1003. https://doi.org/10.1108/JSBED-01-2018-0021

Isichei, Ejikeme Emmanuel, Emmanuel Agbaeze, Kalu, \& Odiba, Maria Onyejeche. (2020). Entrepreneurial orientation and performance in SMEs: The mediating role of structural infrastructure capability. International Journal of Emerging Markets, 15(6), 1219-1241. https://doi.org/10.1108/IJOEM-082019-0671

Kaplan, Robert S., \& Norton, David P. (1992). HarvardBusinessReview KaplanAndNorton(Bala - Onbekend. Harvard Business, 70(1), 71-79.

Kementrian KUKM. (2021). Perkembangan Data Usaha Mikro, Kecil, Menengah, dan Usaha Besar. Www.Depkop.Go.ld, 2000(1), 1.

Khan, Rizwan Ullah, Salamzadeh, Yashar, Kawamorita, Hiroko, \& Rethi, Gabor. (2021). Entrepreneurial Orientation and Small and Medium-sized Enterprises' Performance; Does 'Access to Finance' Moderate the Relation in Emerging Economies? Vision, 25(1), 88-102. https://doi.org/10.1177/0972262920954604

Kiyabo, Kibeshi, \& Isaga, Nsubili. (2020). Entrepreneurial orientation, competitive advantage, and SMEs' performance: application of firm growth and personal wealth measures. Journal of Innovation and Entrepreneurship, 9(1). https://doi.org/10.1186/s13731-020-00123-7

Kulathunga, K. M. M. C. B., Ye, Jianmu, Sharma, Saurabh, \& Weerathunga, P. R. (2020). How does technological and financial literacy influence SME performance: Mediating role of ERM practices. Information (Switzerland), 11(6). https://doi.org/10.3390/INFO11060297

Lumpkin, G. T., \& Dess, Gregory G. (1996). Academy of Management Heview. Academy of Management Review, 21(1), 135-172.

Mabula, Juma Buhimila, \& Ping, Han Dong. (2018). Financial literacy of SME 
managers' on access to finance and performance: The mediating role of financial service utilization. International Journal of Advanced Computer Science and Applications, 9(9), 32-41. https://doi.org/10.14569/ijacsa.2018.090905

Mason, Michela C., Floreani, Josanco, Miani, Stefano, Beltrame, Federico, \& Cappelletto, Roberto. (2015). Understanding the Impact of Entrepreneurial Orientation on Smes' Performance. the Role of the Financing Structure. Procedia Economics and Finance, 23(October 2014), 1649-1661. https://doi.org/10.1016/s2212-5671(15)00470-0

Mor, Surender, Madan, Sonu, Archer, Geoffrey R., \& Ashta, Arvind. (2020). Survival of the Smallest: A Study of Microenterprises in Haryana, India. Millennial Asia, 11(1), 54-78. https://doi.org/10.1177/0976399619900609

Mostapha, Nehale Farid. (2016). Financing of Small and Medium-Sized Enterprises (Smes) in Developing Countries. 169-177.

Nakita Gusman, Subiakto Soekarno, Isti Raafaldini Mirzanti. (2021). The Impact of Founder's Financial Behavior Traits and Literacy on SMEs Performance: Empirical Evidence from SMEs in Indonesia. Jurnal Keuangan Dan Perbankan, 25(3), 671-687. https://doi.org/10.26905/jkdp.v25i3.5142

OECD/INFE. (2018). OECD/INFE Toolkit for Measuring Financial Literacy and Financial Inclusion. Oecd, (March), 1-47.

Rajamani, K., \& A, Nirmal Raj. (2019). Finance for Micro, Small and Medium Enterprises (MSMEs ) - A Conceptual Framework. 16(2), 367-378.

Rita, Maria Rio, \& Thren, Andrew Thomas. (2019). A Three Dimensional Model of MSME Performance an Agenda for Further Research. 12(1), 1-14.

Rita, Maria Rio, \& Wahyudi, Sugeng. (2019). Entrepreneurial finance: financing antecedents and SMEs performance. Journal of Economics, Business \& $\begin{array}{lll}\text { Accountancy } & \text { Ventura, } & 303(3),\end{array}$ https://doi.org/10.14414/jebav.v21i3.1497

Rizki Agung Putra, Muchammad, Firdausi Nuzula, Nila, \& Khalid Mawardi, Muhammad. (2021). Pengaruh Orientasi Kewirausahaan Dan Akses Keuangan Terhadap Kinerja Usaha. Profit, 15(01), 84-94. https://doi.org/10.21776/ub.profit.2021.015.01.9

Satiti, Novita Ratna. (2020). FINANCIAL LITERACY: AN ESSENTIAL IN SMALL MEDIUM ENTREPRISES (SMEs) PERFORMANCE. Manajemen Bisnis, 10(2), 51-61. https://doi.org/10.22219/jmb.v10i2.14825

Sidek, Syamsuriana, Mohamad, Mohd Rosli, \& Nasir, Wan Mohd Nazdrol Wan Mohd. (2016). Entrepreneurial Orientation, Access to Finance and Business Performance: A Preliminary Analysis. International Journal of Academic Research in Business and Social Sciences, 6(11), 692-707. https://doi.org/10.6007/ijarbss/v6-i11/2452 


\title{
Hamdana, Heri Pratikto, Sopiah
}

Susan, Marcellia. (2020). Financial literacy and growth of micro, small, and medium enterprises in west java, indonesia. International Symposia in Economic Theory and Econometrics, 27, 39-48. https://doi.org/10.1108/S1571-038620200000027004

Tambunan, Tulus. (2019). Recent evidence of the development of micro, small and medium enterprises in Indonesia. Journal of Global Entrepreneurship Research, 9(1). https://doi.org/10.1186/s40497-018-0140-4

Utami, Elok Sri, Aprilia, Mega Rizky, \& Putra, Ihrom Caesar Ananta. (2021). Financial Literacy of Micro, Small, and Medium Enterprises of Consumption Sector in Probolinggo City. Jurnal Manajemen Dan Kewirausahaan, 23(1), 10-17. https://doi.org/10.9744/jmk.23.1.10-17

Volpe, Haiyang Chen \&. Ronald P. (1998). An Analysis of Personal Financial Literacy Among College Students. Financial Services Review, 7(2), 107-128. https://doi.org/10.3788/CJL201643.0811001

Wijayanto, Sigit Ary, Wahyullah, Muhammad, \& Aribawa, Dwitya. (2020). the Effect of Entrepreneur Orientation and Financial Literacy Toward Small Business Enterprises Performance in Mataram. Jurnal Benefita, 5(3), 352. https://doi.org/10.22216/jbe.v5i3.5022

Ye, Jianmu, \& Kulathunga, K. M. M. C. B. (2019). How does financial literacy promote sustainability in SMEs? A developing country perspective. Sustainability (Switzerland), 11(10), 1-21. https://doi.org/10.3390/su11102990

Zarrouk, Hajer, Sherif, Mohamed, Galloway, Laura, \& El Ghak, Teheni. (2020). Entrepreneurial Orientation, Access to Financial Resources and SMEs' Business Performance: The Case of the United Arab Emirates. Journal of Asian Finance, Economics and Business, 7(12), 465-474. https://doi.org/10.13106/JAFEB.2020.VOL7.NO12.465

\section{Copyright holder :}

\author{
Hamdana Heri Pratikto, Sopiah (2021)
}

First publication right :

\section{Devotion : Journal of Research and Community Service}

This article is licensed under: 